\title{
Comparison of time-dependent changes in the surface hardness of different composite resins
}

\author{
Suat Ozcan ${ }^{1}$, Ihsan Yikilgan ${ }^{1}$, Mine Betul Uctasli ${ }^{1}$, Oya Bala ${ }^{1}$, Zeliha Gonca Bek Kurklu²
}

Correspondence: Dr. Ihsan Yikilgan

Email: ihsanyikilgan@gazi.edu.tr
'Department of Restorative Dentistry, Faculty of Dentistry, University of Gazi, Ankara, Turkiye 2Public Dentist, Adana, Turkiye

\section{ABSTRACT}

Objective: The aim of this study was to evaluate the change in surface hardness of silorane-based composite resin (Filtek Silorane) in time and compare the results with the surface hardness of two methacrylate-based resins (Filtek Supreme and Majesty Posterior). Materials and Methods: From each composite material, 18 wheel-shaped samples (5-mm diameter and 2-mm depth) were prepared. Top and bottom surface hardness of these samples was measured using a Vicker's hardness tester. The samples were then stored at $37^{\circ} \mathrm{C}$ and $100 \%$ humidity. After $24 \mathrm{~h}$ and 7, 30 and 90 days, the top and bottom surface hardness of the samples was measured. In each measurement, the rate between the hardness of the top and bottom surfaces were recorded as the hardness rate. Statistical analysis was performed by one-way analysis of variance, multiple comparisons by Tukey's test and binary comparisons by $t$-test with a significance level of $P=0.05$. Results: The highest hardness values were obtained from each two surfaces of Majesty Posterior and the lowest from Filtek Silorane. Both the top and bottom surface hardness of the methacrylate based composite resins was high and there was a statistically significant difference between the top and bottom hardness values of only the silorane-based composite, Filtek Silorane $(P<0.05)$. The lowest was obtained with Filtek Silorane. The hardness values of all test groups increased after $24 \mathrm{~h}(P<0.05)$. Conclusion: Although silorane-based composite resin Filtek Silorane showed adequate hardness ratio, the use of incremental technic during application is more important than methacrylate based composites.

Key words: Composite resin, silorane-based composite resin, surface hardness

\section{INTRODUCTION}

The use of light-activated composite resins has increased considerably because they provide better esthetics and an opportunity to restore extensive restorations. The structure of resin matrices of polymerized composite resins comprises bisphenolglycidyl dimethacrylate (Bis-GMA), triethylene glycol dimethacrylate (TEG-DMA) or urethane dimethacrylate (UDMA). ${ }^{[1]}$ In the polymerization of resin-based composites, shrinkage occurs as a result of the change from carbon single to double bonds. This event, called polymerization shrinkage, is the largest cause of stress on the cavity walls, separating the composite material from the cavity walls. Separation of the composite material from the cavity walls reportedly causes microleakage at the margins of the restoration and secondary caries, post-operative sensitivity and dental pulp pathology. ${ }^{[2-4]}$ To overcome the problems associated with polymerization shrinkage, early attempts focused on the type and amount of the particles included in composite resins and on different applications to particle surfaces. Later studies focused on the relationship between the polymerization shrinkage and the monomers composing the organic matrix of composite resins.$^{[5]}$ For this reason, the 3M-ESPE Company developed the silorane matrix system, which differs from methacrylate-based monomers and released the first composite filler material in which this matrix system was used: Filtek Silorane. Silorane actually comprises two different monomers called siloxane and oxirane. ${ }^{[6]}$ Siloxane increases the hydrophobic features of the composite and

\footnotetext{
How to cite this article: Ozcan S, Yikilgan I, Uctasli MB, Bala O, Kurklu ZB. Comparison of time-dependent changes in the surface hardness of different composite resins. Eur J Dent 2013;7:20-5. 
oxirane lowers the level of polymerization shrinkage compared with methacrylate-based composites. In addition, a polymerization reaction peculiar to this composite occurs on the monomer level. ${ }^{[7-9]}$ The manufacturer has announced that this composite can be used easily on posterior Class I and II restorations. Polymerization of light-activated composite resins starts at the surface, where light is applied. ${ }^{[10,11]}$ For this reason, sufficient polymerization cannot be provided toward the deepest parts of the restoration when using bulk technique. Insufficient polymerization may result in sensitivities, discoloration and the formation of marginal gaps in the restoration. ${ }^{[2]}$ The degree of polymerization of resin-based restorative materials can be analyzed directly or indirectly using the different techniques. Direct methods such as laser Raman spectroscopy ${ }^{[12]}$ and infrared spectroscopy ${ }^{[13]}$ are complicated, expensive and time-consuming. ${ }^{[14]}$ Indirect methods include techniques such as scraping, ${ }^{[15]}$ visual evaluation, ${ }^{[16]}$ and surface hardness. ${ }^{[17]}$ Surface hardness is an accepted indicator of the polymerization degree and has been used in many studies. It is simpler than other techniques ${ }^{[18]}$ and shows correlations with data gathered from the infrared spectroscopy method. ${ }^{[19-21]}$

Surface hardness of composite resins can be affected by factors such as the density and application time of the curing light as well as the structure, thickness and color of the material. ${ }^{[22-24]}$ Ideally, surface hardness of the composite resin should be equal or close to equal throughout the restoration and for the life of the restoration. However, the surface hardness of composite resins differs over time. ${ }^{[25]}$

Many studies have analyzed the surface hardness of methacrylate-based composite resins with various techniques. ${ }^{[26-28]}$
The aim of this study was to evaluate the change in surface hardness of silorane- and composite resin-based restorative materials at different time intervals and compare the findings with the surface hardness of two different methacrylate-based composite resins.

\section{MATERIALS AND METHODS}

The composite resins used in the study are shown in Table 1.

To evaluate the surface hardness of each composite material, 18 cylindrically shaped samples were prepared using $5 \mathrm{~mm}$ diameter and $2 \mathrm{~mm}$ deep Teflon molds. During the sample preparation, the Teflon molds were positioned over an acetate strip on a glass plaque. After composite resin insertion, a second acetate strip was placed on top of the mold with slight pressure to remove excess material from the mold. The composite materials were then light-cured with a light-emitting diode (LED) device $\left(1000 \mathrm{mw} / \mathrm{cm}^{2}\right)$ (Hilux, Benlioğlu, Turkey) for $40 \mathrm{~s}$ according to the manufacturer's instructions and the acetate strips were removed.

The top and bottom hardness of the samples was measured using Vicker's hardness tester (HMV-II; Shimadzu, Japan). A 100-g load was applied through the indenter with a dwell time of $15 \mathrm{~s}$. Measurements was performed 3 times for each sample at intervals of $0.5 \mathrm{~mm}$. The first hardness measurements were then recorded. Following the first measurements, samples were stored at $37^{\circ} \mathrm{C}$ and $100 \%$ humidity for $24 \mathrm{~h}$ and 7, 30 and 90 days. Their surface hardness was re-measured and recorded. Afterward, by dividing the bottom surface hardness value by that of the top, the hardness ratio of the material was calculated.

\begin{tabular}{|c|c|c|c|c|c|c|}
\hline Material & Type & Shade & Content & $\begin{array}{l}\text { Batch } \\
\text { number }\end{array}$ & $\begin{array}{c}\text { Filler } \\
\text { content (\%) }\end{array}$ & Filler particle size \\
\hline $\begin{array}{l}\text { Filtek Silorane } \\
\text { 3M-ESPE, USA }\end{array}$ & $\begin{array}{l}\text { Silorane based } \\
\text { microhibrid } \\
\text { composite resin }\end{array}$ & $\mathrm{A} 2$ & $\begin{array}{l}\text { Siloxane, oxirane, camphorquinone, } \\
\text { iodonium salt, electron } \\
\text { donor, quatz, yitrium floride, } \\
\text { stabilizer and pigments }\end{array}$ & $\begin{array}{l}\text { \#8CN } \\
\text { \#9ET }\end{array}$ & 55 (vol.) & $0.1-2 \mu \mathrm{m}$ \\
\hline $\begin{array}{l}\text { Filtek Supreme } \\
\text { 3M-ESPE, USA }\end{array}$ & $\begin{array}{l}\text { Methacrylate } \\
\text { based nanofiller } \\
\text { composite resin }\end{array}$ & $\mathrm{A} 2$ & $\begin{array}{l}\text { Bis-GMA, Bis-EMA, UDMA, } \\
\text { TEGDMA, zirconia/silica }\end{array}$ & \#5BW & 59.5 (vol.) & $\begin{array}{l}\text { Particle size }=20-75 \mathrm{~nm} \text {, } \\
\text { cluster size }=0.6-1.4 \mu \mathrm{m}\end{array}$ \\
\hline $\begin{array}{l}\text { Majesty } \\
\text { Posterior } \\
\text { Kuraray, Japan }\end{array}$ & $\begin{array}{l}\text { Methacrylate } \\
\text { based nanofiller } \\
\text { posterior } \\
\text { composite resin }\end{array}$ & $\mathrm{A} 2$ & $\begin{array}{l}\text { Bis-GMA, TEGDMA, hydrophobic } \\
\text { aromatic dimethacrylate, nano-sized } \\
\text { alumina and glass-ceramic } \\
\text { components, camphorquinone, } \\
\text { accelerator and pigments }\end{array}$ & $\# 00005 B$ & 82 (vol.) & $\begin{array}{l}\text { Nanofiller: } 20 \mathrm{~nm} \text {, } \\
\text { Microfiller: } 1.5 \mathrm{~mm}\end{array}$ \\
\hline
\end{tabular}


Statistical analysis was performed using the one-way analysis of variance, multiple comparisons were conducted using Tukey's test and binary comparisons were made by $t$-test at a significance level of $P=0.05$.

\section{RESULTS}

Mean top and bottom surface hardness values of the composite resins are given in Tables 2-4 and the change in surface hardness values over time is shown in Figure 1.

When the surface hardness values of the three composites were compared, only the silorane-based restorative material (Filtek Silorane) showed statistically significant differences $(P<0.05)$.

The methacrylate-based composite Majesty Posterior showed the highest and the silorane-based composite showed the lowest microhardness values for both the top and bottom surfaces at all measuring periods.

The ratio of top and bottom surface microhardness values, which was termed the hardness ratio, varied between 0.85 and 0.98 . The lowest hardness ratio was obtained from the silorane-based composite Filtek Silorane [Table 5]. Significant differences among the

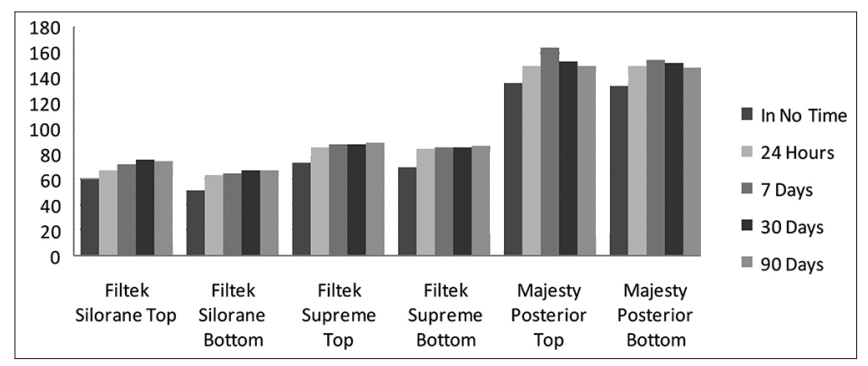

Figure 1: The change in surface hardness values over time hardness ratios of the three composite resins were detected $(P<0.05)$.

When the correlation among Vicker's hardness values obtained immediately after polymerization and after $24 \mathrm{~h}$ and 7 and 30 days was analyzed, there was a statistically significant difference between the immediate and $24 \mathrm{~h}$ measurements on the top surface of the three composite resins. However, a significant difference between $24 \mathrm{~h}$ and 7 days and between 7 days and 30 days was observed only in the samples of the methacrylate-based composite Majesty Posterior $(P<0.05)$. No significant differences were observed on the top surfaces of all three composite resins between 30 and 90 days $(P>0.05)$.

When the difference based on time of the bottom surface hardness of the samples was analyzed, all immediate hardness values of the tested materials showed a significant increase after $24 \mathrm{~h}(P<0.05)$. The hardness values between $24 \mathrm{~h}$ and 7 and 30 days did not show a statistically significant difference $(P>0.05)$.

\section{DISCUSSION}

One of the most important factors affecting the clinical success of nanofiller composite resins, such as microfiller and hybrid composite resins is the materials polymerization throughout the restoration. Adequate polymerization is important in terms of the ideal physical and mechanical properties. As a result of inadequate polymerization, possible microleakage at the margins of the restoration, discoloration, increased erosion, decreased mechanical strength, increased water absorption and decreased bonding strength have been reported. ${ }^{[29,30]}$ In addition, the residual monomers released due to inadequate

\begin{tabular}{|c|c|c|c|c|c|c|c|c|c|}
\hline \multicolumn{2}{|c|}{ Immediately } & \multicolumn{2}{|c|}{$24 \mathrm{~h}$} & \multicolumn{2}{|c|}{7 days } & \multicolumn{2}{|c|}{30 days } & \multicolumn{2}{|c|}{90 days } \\
\hline Top & Bottom & Top & Bottom & Top & Bottom & Top & Bottom & Top & Bottom \\
\hline 58.72 & 50.16 & 66.6 & 62.77 & 71.01 & 64.63 & 74.32 & 66.52 & 73.78 & 66.9 \\
\hline
\end{tabular}

\begin{tabular}{|c|c|c|c|c|c|c|c|c|c|}
\hline \multicolumn{2}{|c|}{ Immediately } & \multicolumn{2}{|c|}{$24 \mathrm{~h}$} & \multicolumn{2}{|c|}{7 days } & \multicolumn{2}{|c|}{30 days } & \multicolumn{2}{|c|}{90 days } \\
\hline Top & Bottom & Top & Bottom & Top & Bottom & Top & Bottom & Top & Bottom \\
\hline 72.478 & 69.1 & 85 & 83.3 & 87.14 & 84.35 & 87.07 & 84.78 & 88.13 & 85.72 \\
\hline
\end{tabular}

\begin{tabular}{|c|c|c|c|c|c|c|c|c|c|}
\hline \multicolumn{2}{|c|}{ Immediately } & \multicolumn{2}{|c|}{$24 h$} & \multicolumn{2}{|c|}{7 days } & \multicolumn{2}{|c|}{30 days } & \multicolumn{2}{|c|}{90 days } \\
\hline Top & Bottom & Top & Bottom & Top & Bottom & Top & Bottom & Top & Bottom \\
\hline 135.5 & 132.83 & 149.05 & 148.722 & 163.39 & 153.611 & 152.22 & 150.5 & 149.16 & 147.33 \\
\hline
\end{tabular}




\begin{tabular}{|c|c|c|c|c|c|}
\hline Material & In no time & $24 \mathrm{~h}$ & 7 days & 30 days & 90 days \\
\hline Filtek Silorane & 0.85 & 0.94 & 0.91 & 0.89 & 0.90 \\
\hline Filtek Supreme & 0.95 & 0.98 & 0.96 & 0.97 & 0.97 \\
\hline Majesty Posterior & 0.98 & 0.99 & 0.94 & 0.98 & 0.98 \\
\hline
\end{tabular}

polymerization may pass through dentin tubules and cause irreversible damage.

Measurement of surface hardness is an indirect method of evaluating the polymerization degree of composite resin. Researchers have used different hardness measurement tests, such as those of Vicker, Barcoll and Knoop. Vicker's hardness test is easy to apply and the data obtained are reliable. The diamond indenter used in the procedure does not deform over time and is reportedly suitable for measurement of the hardness of fragile materials and dental tissue. ${ }^{[31]}$ In the present study, the surface hardness of two methacrylate-based composite resins and one silorane-based composite was compared using Vicker's hardness measurement device.

The hardness of composite resin is reportedly affected by the color and depth of the composite material used as well as by the light device, period of light application and distance between the light tip and composite resin surface. ${ }^{[22-24]}$ For this reason, the thickness of the samples was standardized to $2 \mathrm{~mm}$ in the present study. To avoid the effects of color on hardness, all three composites used in the study were of A2 color. All samples were polymerized using the same LED light device for $40 \mathrm{~s}$, the light was implemented through a glass slab and the distance between the light device and the sample was anchored.

On both the top and bottom surfaces in all measurement periods, the highest hardness value was obtained in the samples of the methacrylate-based nanofiller composite Majesty Posterior and the lowest was obtained in the samples of the silorane-based composite Filtek Silorane. Guiraldo et al. ${ }^{[28]}$ compared the top and bottom surface hardness of methacrylate- and silorane-based composite resins and found that the bottom surface value of the silorane-based composite resin was statistically significantly higher. Kusgoz et al. ${ }^{[32]}$ have obtained similar results These findings support the data obtained in this study.

There was a statistically significant difference among the hardness values of the composite resins used in this study. The reason for this difference is that the monomer types, filler types and filler volume and polymerization mechanism of the composite resins used in the study differed. ${ }^{[29]}$ In methacrylate-based composites, proximity of monomers react to establish a covalent bond in the polymerization process. On the other hand, the ring opening chemistry promotes expansion of the molecule during the polymerization process. The kinetics of the initiation and polymerization begin with cleavage and opening of the ring systems through a cationic ring opening reaction. ${ }^{[33]}$ The resin matrix of one of the methacrylate-based composite resins, Majesty Posterior, comprises Bis-GMA and TEGDMA. Filtek Supreme, on the other hand, comprises Bis-GMA, TEGDMA, Bis-EMA and UDMA. The filler ratio of these materials is $82 \%$ for Majesty Posterior and $59.5 \%$ for Filtek Supreme volumetrically. The size of the filler particles is similar between the two.

In the silorane-based composite Filtek Silorane, which showed the lowest hardness degree, a silorane monomer was used. This type of monomer comprises siloxane and oxirane monomers in contrast to methacrylate-based composite resins. In addition, polymerization of this composite resin is quite different from the polymerization reaction of methacrylate-based composite resins. The main photoinitiator responsible for starting polymerization in methacrylate-based composites is camphorquinone. The reaction of this chemical with tertiary amines generates free radicals. In silorane-based composites, three main photoinitiators were used. These were camphorquinone, an iodonium salt and an electron donor. Camphorquinone was used because it is consistent with the emission spectra of the light used in the light devices. The electron donor, on the other hand, is come down to resolve the iodonium salt in an acidic cation and a split ring polymerization reaction is thus initiated. ${ }^{[7]}$

There were no significant differences between the top and bottom surfaces of the two methacrylate-based composites, whereas there was a significant difference between the top and bottom surface hardness of the silorane-based composite Filtek Silorane. Previous studies showed that the difference in hardness between the top and bottom surfaces of the composite resins was caused by inadequate light reaching the deep parts of the composite material. ${ }^{[29,32-35]}$ In addition, while some of the light was absorbed by the composite material, some of it was shed. ${ }^{[32]}$ This situation prevents the light from adequately penetrating the deeper parts of the composite material. 
The top and bottom surface hardness values gathered from in vitro studies do not always indicate inadequate polymerization. For this reason, it is important to define a hardness ratio that states the ratio between the top and bottom hardness values in such studies. Ideally, these top and bottom surface hardness values are expected to be similar. ${ }^{[36]}$ Pilo and Caardash ${ }^{[37]}$ stated that the hardness value should be $>0.80$. All materials analyzed in this study had a hardness value of $>0.85$. This suggests that the LED light curing was adequate for polymerization of the $2 \mathrm{~mm}$ thick methacrylate and silorane-based composite samples.

In all three composites resins used in this study, the top and bottom surface hardness values differed significantly in the $1^{\text {st }} 24 \mathrm{~h}$. This is an indication that the polymerization reaction continues in the $1^{\text {st }} 24 \mathrm{~h}$. Previous studies have shown that microhardness values of composite resins are not constant and increase with time. Researchers suppose that unreacted free-radicals in the structure lead this event by continuing to generate cross-links after light application. ${ }^{[38-40]}$ According to the day 7 data, the hardness values of all three composite resins decreased, followed by a relative increase. Our results support this information. Restorative material is affected by the saliva in the mouth and the food eaten. Ideally, the restorative material is expected to remain stable in the mouth. However, polymer-structured composite materials tend to absorb water and dissolve there in. Studies have shown a correlation between the water absorption and dissolving characteristics in water of composite resins. ${ }^{[41,42]}$ Pereira et al..$^{[43]}$ analyzed the physicochemical features of restorative materials including different fillers and stated that when the filler amount increased, composite materials tended to absorb less water and exhibited lower solubility. The filler amount of the silorane-based composite resin Filtek Silorane was lower than that of the other two methacrylate-based composites. Y1kilgan et al. ${ }^{[44]}$ stated that the water absorption and water solubility of silorane-based composite resins were greater than those of the methacrylate-based composites. This might be why the silorane-based composite Filtek Silorane exhibited lower top and bottom surface hardness values and a lower hardening rate.

\section{CONCLUSION}

Although silorane-based composite resin Filtek Silorane showed adequate hardness ratio, the use of incremental technic during application is more important than methacrylate based composites. Because both the top and bottom surface hardness values of the silorane-based composite resin Filtek Silorane were lower than those of the methacrylate-based composite resins and there was a significant difference between the top and bottom surface hardness values of the silorane-based composite resin Filtek Silorane.

\section{REFERENCES}

1. Sideridou ID, Achilias DS. Elution study of unreacted Bis-GMA, TEGDMA, UDMA, and Bis-EMA from light-cured dental resins and resin composites using HPLC. J Biomed Mater Res B Appl Biomater 2005;74:617-26.

2. Irie M, Suzuki K, Watts DC. Marginal gap formation of light-activated restorative materials: Effects of immediate setting shrinkage and bond strength. Dent Mater 2002;18:203-10.

3. Loguercio AD, Reis A, Schroeder M, Balducci I, Versluis A, Ballester RY. Polymerization shrinkage: Effects of boundary conditions and filling technique of resin composite restorations. J Dent 2004;32:459-70.

4. Yoshikawa T, Burrow MF, Tagami J. A light curing method for improving marginal sealing and cavity wall adaptation of resin composite restorations. Dent Mater 2001;17:359-66.

5. Ilie N, Jelen E, Clementino-Luedemann T, Hickel R. Low-shrinkage composite for dental application. Dent Mater J 2007;26:149-55.

6. Shenoy A. Is it the end of the road for dental amalgam? A critical review. J Conserv Dent 2008;11:99-107.

7. Weinmann W, Thalacker C, Guggenberger R. Siloranes in dental composites. Dent Mater 2005;21:68-74.

8. Tilbrook DA, Clarke RL, Howle NE, Braden M. Photocurable epoxy-polyol matrices for use in dental composites I. Biomaterials 2000;21:1743-53.

9. Eick JD, Kostoryz EL, Rozzi SM, Jacobs DW, Oxman JD, Chappelow CC, et al. In vitro biocompatibility of oxirane/polyol dental composites with promising physical properties. Dent Mater 2002;18:413-21.

10. Anusavice KJ. Phillip's Science of Dental Materials. $11^{\text {th }}$ ed. St. Louis: Elsevier; 2003.

11. Ruyter IE, Oysaed H. Conversion in denture base polymers. J Biomed Mater Res 1982;16:741-54.

12. Louden JD, Roberts TA, Cure profiles of light cured dental composites by Raman spectroscopy. J Raman Spectrosc 1983;14:167-70.

13. Aguiar FH, Braceiro AT, Ambrosano GM, Lovadino JR. Hardness and diametral tensile strength of a hybrid composite resin polymerized with different modes and immersed in ethanol or distilled water media. Dent Mater 2005;21:1098-103.

14. Rueggeberg FA, Craig RG. Correlation of parameters used to estimate monomer conversion in a light-cured composite. J Dent Res 1988;67:932-7.

15. Cook WD. Factors affecting the depth of cure of UV-polymerized composites. J Dent Res 1980;59:800-8.

16. Murray GA, Yates JL, Newman SM. Ultraviolet light and ultraviolet light-activated composite resins. J Prosthet Dent 1981;46:167-70.

17. Asmussen E. Factors affecting the quantity of remaining double bonds in restorative resin polymers. Scand J Dent Res 1982;90:490-6.

18. Yap AU. Effectiveness of polymerization in composite restoratives claiming bulk placement: Impact of cavity depth and exposure time. Oper Dent 2000;25:113-20.

19. Bouschlicher MR, Rueggeberg FA, Wilson BM. Correlation of bottom-to-top surface microhardness and conversion ratios for a variety of resin composite compositions. Oper Dent 2004;29:698-704.

20. Knobloch L, Kerby RE, Clelland N, Lee J. Hardness and degree of conversion of posterior packable composites. Oper Dent 2004;29:642-9.

21. Vandewalle KS, Ferracane JL, Hilton TJ, Erickson RL, Sakaguchi RL. Effect of energy density on properties and marginal integrity of posterior resin composite restorations. Dent Mater 2004;20:96-106.

22. Davidson-Kaban SS, Davidson CL, Feilzer AJ, de Gee AJ, Erdilek N. The effect of curing light variations on bulk curing and wall-to-wall quality of two types and various shades of resin composites. Dent Mater 1997;13:344-52.

23. Yap AU, Wong NY, Siow KS. Composite cure and shrinkage associated with high intensity curing light. Oper Dent 2003;28:357-64. 
24. Guiraldo RD, Consani S, Consani RL, Berger SB, Mendes WB, Sinhoreti MA. Light energy transmission through composite influenced by material shades. Bull Tokyo Dent Coll 2009;50:183-90.

25. Schneider LF, Consani S, Ogliari F, Correr AB, Sobrinho LC, Sinhoreti MA. Effect of time and polymerization cycle on the degree of conversion of a resin composite. Oper Dent 2006;31:489-95.

26. Correr AB, Sinhoreti MA, Sobrinho LC, Tango RN, Schneider LF, Consani $\mathrm{S}$. Effect of the increase of energy density on knoop hardness of dental composites light-cured by conventional QTH, LED and xenon plasma arc. Braz Dent J 2005;16:218-24.

27. Bauer $H$, Ilie N. Effects of aging and irradiation time on the properties of a highly translucent resin-based composite. Dent Mater J. 2013;32:592-9

28. Guiraldo RD, Consani S, Consani RL, Berger SB, Mendes WB, Sinhoreti MA, et al. Comparison of silorane and methacrylate-based composite resins on the curing light transmission. Braz Dent J 2010;21:538-42.

29. Venhoven BA, de Gee AJ, Davidson CL. Polymerization contraction and conversion of light-curing BisGMA-based methacrylate resins. Biomaterials 1993;14:871-5.

30. Shortall AC, Wilson HJ, Harrington E. Depth of cure of radiation-activated composite restoratives - Influence of shade and opacity. J Oral Rehabil 1995;22:337-42.

31. Mitra SB, Wu D, Holmes BN. An application of nanotechnology in advanced dental materials. J Am Dent Assoc 2003;134:1382-90.

32. Kusgoz A, Ülker M, Yesilyurt C, Yoldas OH, Ozil M, Tanriver M. Silorane-based composite: Depth of cure, surface hardness, degree of conversion, and cervical microleakage in Class II cavities. J Esthet Restor Dent 2011;23:324-35.

33. Bechtold J, Dos Santos PJ, Anido-Anido A, Di Hipólito V, Alonso RC, D)Alpino PH. Hardness, polymerization depth, and internal adaptation of Class II silorane composite restorations as a function of polymerization protocol. Eur J Dent 2012;6:133-40.

34. Rueggeberg FA, Caughman WF, Curtis JW Jr, Davis HC. Factors affecting cure at depths within light-activated resin composites. Am J Dent 1993;6:91-5.

35. Mousavinasab SM, Meyers I. Comparison of depth of cure, hardness and heat generation of LED and high intensity QTH light sources. Eur J Dent 2011;5:299-304.

36. Emami N, Sjödahl M, Söderholm KJ. How filler properties, filler fraction, sample thickness and light source affect light attenuation in particulate filled resin composites. Dent Mater 2005;21:721-30.

37. Pilo R, Cardash HS. Post-irradiation polymerization of different anterior and posterior visible light-activated resin composites. Dent Mater 1992;8:299-304.

38. Gress JE, Matsumato H, Marker VA, Okabe T, Ferracane JL, Harvey GA. Depth of cure of visible light cured composites-clinical simulation. Dent Abstr 1984;293:1097.

39. Bassiouny MA, Grant AA. Physical properties of a visible-light-cured composite resin. J Prosthet Dent 1980;43:536-41.

40. Watts DC, Amer OM, Combe EC. Surface hardness development in light-cured composites. Dent Mater 1987;3:265-9.

41. Ito S, Hashimoto M, Wadgaonkar B, Svizero N, Carvalho RM, Yiu C, et al. Effects of resin hydrophilicity on water sorption and changes in modulus of elasticity. Biomaterials 2005;26:6449-59.

42. Ferracane JL. Hygroscopic and hydrolytic effects in dental polymer networks. Dent Mater 2006;22:211-22.

43. Pereira SG, Osorio R, Toledano M, Cabrerizo-Vílchez MA, Nunes TG, Kalachandra S. Novel light-cured resins and composites with improved physicochemical properties. Dent Mater 2007;23:1189-98.

44. Yikılgan I, Gurel MA, Bala O, Omurlu H. Comparison of water sorption and solubility of different restorative materials J Gazi Uni Fac Dent 2010;27:93-8

\begin{tabular}{|c|c|}
\hline \multicolumn{2}{|c|}{ Access this article online } \\
\hline $\begin{array}{l}\text { Quick Response Code: } \\
\end{array}$ & $\begin{array}{l}\text { Website: } \\
\text { www.eurjdent.com }\end{array}$ \\
\hline $1+2=$ & $\begin{array}{l}\text { Source of Support: Nil. } \\
\text { Conflict of Interest: None declared }\end{array}$ \\
\hline
\end{tabular}

\section{Author Help: Online submission of the manuscripts}

Articles can be submitted online from http://www.journalonweb.com. For online submission, the articles should be prepared in two files (first page file and article file). Images should be submitted separately.

\section{1) First Page File:}

Prepare the title page, covering letter, acknowledgement etc. using a word processor program. All information related to your identity should be included here. Use text/rtt/doc/pdf files. Do not zip the files.

2) Article File:

The main text of the article, beginning with the Abstract to References (including tables) should be in this file. Do not include any information (such as acknowledgement, your names in page headers etc.) in this file. Use text/rtf/doc/pdf files. Do not zip the files. Limit the file size to $1024 \mathrm{~kb}$. Do not incorporate images in the file. If file size is large, graphs can be submitted separately as images, without their being incorporated in the article file. This will reduce the size of the file.

3) Images:

Submit good quality color images. Each image should be less than $\mathbf{4 0 9 6} \mathbf{~ k b ~ ( 4 ~ M B ) ~ i n ~ s i z e . ~ T h e ~ s i z e ~ o f ~ t h e ~ i m a g e ~ c a n ~ b e ~ r e d u c e d ~ b y ~}$ decreasing the actual height and width of the images (keep up to about 6 inches and up to about $1800 \times 1200$ pixels). JPEG is the most suitable file format. The image quality should be good enough to judge the scientific value of the image. For the purpose of printing, always retain a good quality, high resolution image. This high resolution image should be sent to the editorial office at the time of sending a revised article.

4) Legends:

Legends for the figures/images should be included at the end of the article file. 